\title{
Angles
}

New Perspectives on the Anglophone World

$10 \mid 2020$

Creating the Enemy

\section{The Evil Savage Other as Enemy in Modern U.S. Presidential Discourse}

Jérôme Viala-Gaudefroy

\section{OpenEdition}

1 Journals

\section{Electronic version}

URL: http://journals.openedition.org/angles/498

DOI: $10.4000 /$ angles.498

ISSN: 2274-2042

\section{Publisher}

Société des Anglicistes de l'Enseignement Supérieur

\section{Electronic reference}

Jérôme Viala-Gaudefroy, "The Evil Savage Other as Enemy in Modern U.S. Presidential Discourse », Angles [Online], 10 | 2020, Online since 01 April 2020, connection on 28 July 2020. URL : http:// journals.openedition.org/angles/498; DOI : https://doi.org/10.4000/angles.498

This text was automatically generated on 28 July 2020 .

\section{(c) (i) (2)(2)}

Angles. New Perspectives on the Anglophone World is licensed under a Creative Commons AttributionNonCommercial-ShareAlike 4.0 International License. 


\title{
The Evil Savage Other as Enemy in Modern U.S. Presidential Discourse
}

\author{
Jérôme Viala-Gaudefroy
}

1 Most scholars in international relations hold the view that our knowledge of the world is a human and social construction rather than the mere reflection of reality (Wendt 1994; Finnemore 1996). This perspective, rooted in constructivist epistemology, implies that nations are not unquestionable ancient natural quasi-objective entities, as primordialist nationalists claim, but rather cognitive constructions shaped by stories their members imagine and relate. ${ }^{1}$ This was famously illustrated by Benedict Anderson's study of nationalism that reached the compelling conclusion that any community "larger than that primordial village of face-to-face contact" can only be imagined (Anderson 1983: 6). The identity of a nation is undoubtedly dependent on stories its members imagine and relate. As with any form of identity, whether collective or individual, national identity is constituted in relation to difference. Communication scholar Jeremy Engels sees in "the rhetoric of enemyship" a "lasting rhetorical strategy for asserting the centrality of oneness in American politics" since the founding period (Engels 2015: 26). Relying on research in the fields of communication (Coe and Neuman 2011; Edwards 2008; Ivie 1980; Stuckey 2004), sociology (Coles 2002), political science (Campbell 1992), and cognitive linguistics (Lakoff and Johnson), this paper will analyze the construction of national enemies through the Savagery trope in the discourse of contemporary U.S. presidents.

2 In the words of political scientist David Campbell, one of the distinctive features of the American national identity is that it is "the imagined community par excellence," as its identity depends neither on a territory, nor on a homogenous people, nor even on an ancient common history and heritage (Campbell 1992: 105). Relying on the power of imagination through discourse, it is constantly defined at least as much by absence as by presence, by what it is not as much as by what it may be. ${ }^{2}$ One central feature of the American national identity is precisely its contingence on the existence of an evil Other identified since its foundation as liberty's adversary: from Great Britain and monarchical Europe to fascism, communism and terrorism (Caldwell 2006: 20; Ivie 2005: 
11; Foner 2001: 5). This threatening Other is presented as causing and justifying America's unique penchant for violence (Caldwell 2006: 27). But, as American scholar Richard Slotkin observed, "what is distinctively 'American' is not the amount of violence that characterizes [its] history but the mythic significance [...] assigned [to it]" (Slotkin 1993:13).

3 Even though myths permeate many aspects of American society, especially its popular culture, the presidency remains the most important institution for telling the national myth (Coe and Neuman 2011: 142). As the only representative elected by all the adult citizens, the President is the embodiment of the nation and the single political figure who can take on the role of the "Storyteller-in-Chief." He has both the constitutional and symbolic power to set goals and give meaning to the national community. Above all, as Chief Executive and Commander-in-Chief of the armed forces, his greatest responsibility is to protect the nation, define its threats, and name its enemies.

4 Central to the construction of the enemy image in presidential discourse is the use of the savagery trope (Ben-Porath 2007:182). Communication scholars Robert Ivie (1980), Mark West and Christ Carey (2006), Zoë Hess Carney and Mary Stuckey (2016) and historian Richard Slotkin (1993), have long demonstrated the relevance of the imagery of the "savage Other" in portraying America's enemies in presidential rhetoric, be it during the Vietnam war, the Cold War, or the War on Terror, to name only the most recent conflicts. Naturally, naming the Other as "Savage" is also a way to cast the Self as civilized and to raise the stakes of wars and conflicts as crucial undertakings in a universal battle for the very existence of civilization.

Extending the work of other academics on presidential war discourse, rhetorical scholars have distinguished two categories of "savage" imagery to depict America's enemies: the primitive and the modern savage (Butler 2002: 18; Edwards 2008: 832). The "primitive savage" is devoid of all the attributes of civilization. This image can be traced back to the portrayal of "the Indian" in the myth of the Frontier and is associated with chaos and the absence of order or state. The "modern savage," on the other hand, has a semblance of civilization and a "level of cultural sophistication," while remaining outside the civilized world because of his barbaric actions (Butler 2002: 14). This is typified by Hitler or Stalin, but also the British during the Revolutionary war (Ivie 1980: 283).

We will consider the period since the end of the Cold War, from George $\mathrm{H}$. Bush through Donald Trump, a challenging period when presidents could no longer rely on an easily identifiable monolithic enemy in their foreign policy rhetoric (Edwards 2008a: 841). We will address two major and concurrent aspects of the function of the enemy image in presidential rhetoric: on the one hand, its circumstantial political role in mobilizing the American people in support of policy, and, on the other, its more deeply-rooted significance in shaping the national narrative and identity.

7 This article will begin by considering the religious terminology used by presidents to construct the enemy image. This language reflects a binary worldview that not only assumes the existence of evil, but also gives an apocalyptic dimension to world conflicts. This eschatological perspective is a distinct characteristic of American presidential rhetoric that can be traced back to the Jeremiad, the political sermon of the $17^{\text {th }}$ century. We will next focus on the figure of the "primitive savage," another distinctively American feature that echoes the myth of the Frontier at the center of the dehumanizing process of the adversary. Much as this portrayal of the enemy seemed 
particularly suited to the smaller conflicts of the immediate post-Cold War period of the 1990s, it did not constitute a big enough threat to justify large military actions such as the Gulf War or the Iraq War. Our third section will examine the other important aspect of the iconic American villain: the "modern savage," whose development is connected to the use of the World War II analogy, a war that remains the matrix of all modern wars. Finally, in our last part, we will discuss how Donald Trump has resorted to war metaphors to build a discourse of clear and imminent danger based on the enemy's proximity, identified as both modern (news media, the elite, etc.) and primitive (immigrants, the MS-13 gang), located significantly both inside and outside the national territory. This double exclusion, which has deep historical roots in the United States, can also be found woven into the fabric of populist rhetoric, especially through a rhetoric of disgust at the Other.

\section{The Evil Other}

8 American presidential rhetoric has long been characterized by the fusion of religious and secular elements. The way the enemy image has often been crafted as "evil" by presidents and their speechwriters, for instance, is a good illustration of how a purposeful moral and religious dimension can be created. One of the most famous and successful uses of the word "evil" in modern history was Ronald Reagan's "evil empire" that served to antagonize the Soviet Union, escalate the Cold War in the 1980s, and please his conservative religious audience (Goodnight 1986: 403). More recently, following the terrorist attacks on September 11, 2001, George W. Bush employed the phrase "axis of evil" to give notice to the world about Iran, Iraq and North Korea (2002-01-29). The word "evil" was chosen by George W. Bush's speechwriters, who had initially considered the phrase "axis of hatred" before deliberately and carefully settling on the epithet "evil" to reflect the president's strong religious beliefs and his view of a larger "fight between good and evil" (Frum 2003: 238; 2001-11-28).

Republican and Democratic presidents alike have all affirmed the presence of evil because what matters is not the specific form evil takes but the fact that it exists. In his Nobel Peace Prize acceptance remarks, for instance, Barack Obama reminded his audience that "evil does exist" (2009-12-10). American presidents not only publicly assume that evil exists as a powerful force in the world, but also that evil is the same enemy that the U.S. has been fighting all along in all its wars, only with different faces. "At its core," said George W. Bush, "it is an ancient battle between good and evil" (2008-05-15). Similarly, talking at NATO headquarters in 2017, Donald Trump portrayed the Cold War and the September 11, 2001 terrorist attacks as events "in the eternal battle between good and evil" (2017-05-25).

To define a threatening Other as evil is also a way to designate the Self as good. In the case of America, this Self is believed to be virtuous and blessed by God for doing God's work. Evil actions reveal the character of the national community: "And as a result of this evil," concluded George W. Bush, "we're assessing ourselves" (2002-03-08). "Out of this evil," he said elsewhere, "this Nation has shown the world what a compassionate, kind place we are" (2002-03-01). Of all presidents since Franklin D. Roosevelt, George W. Bush has used the word "evil" the most often by far. 
Figure 1. Percentage of speeches and remarks containing the word "evil" in presidential speeches

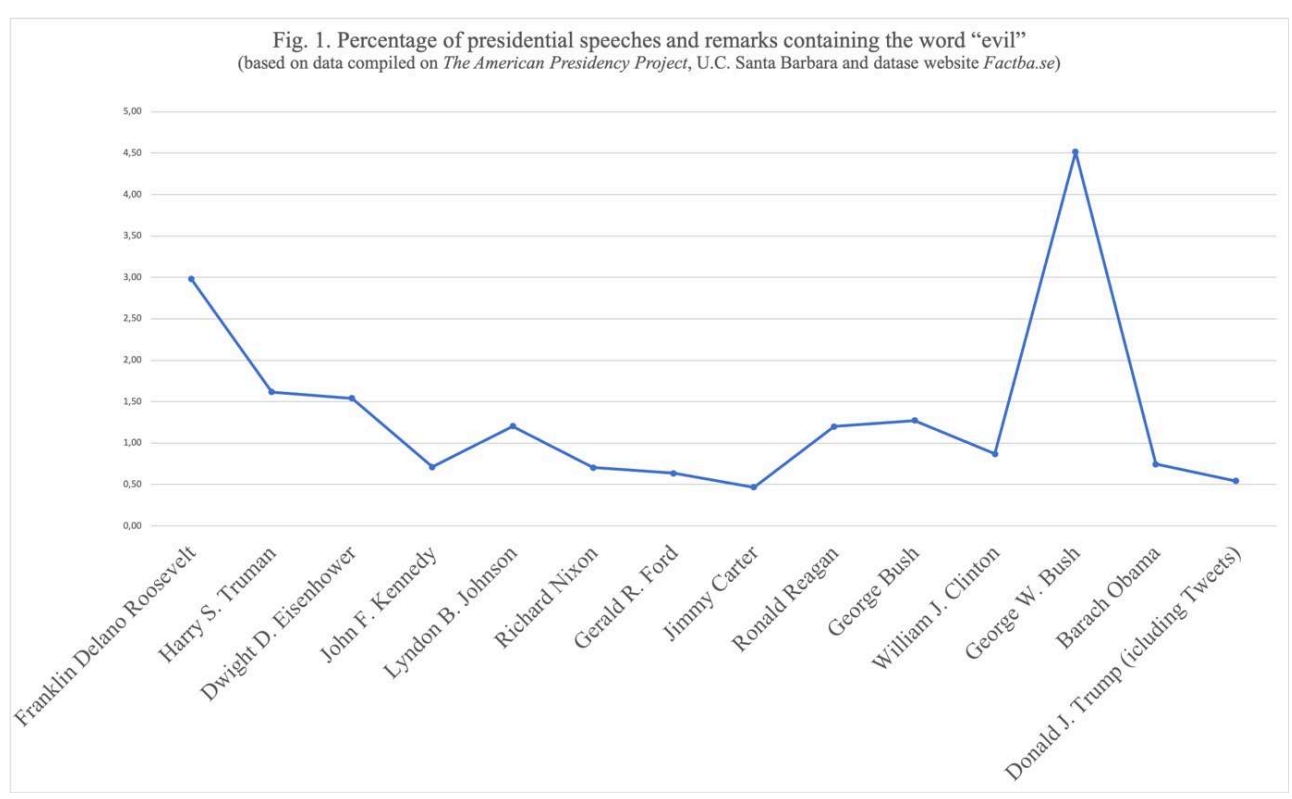

Based on data compiled on the American Presidency Project, UC Santa Barbara

11 This is not surprising from a president with strong evangelical beliefs and an eschatological vision of the world, which shaped his interpretation of $9 / 11$ as an illustration of the eternal drama of the fight between good and evil (Murphy 2003: 623). In his address to the nation on the very day of the attacks, he said "thousands of lives were suddenly ended by evil, despicable acts of terror [...]. Today our Nation saw evil, the very worst of human nature." (2001-09-11) As this case shows, evoking "evil" enables presidents to name and personify an unidentified enemy not in terms of national security or foreign policy, but in moral and religious terms.

Evil is America's needed nemesis. It enables the United States to redefine itself and rediscover its "strength" (2015-07-10), its "collective goodness" (2002-02-16) and its "unity" (2017-02-28). This binary view is reinforced by the recurrent use of the biblical motif of light vs. darkness (particularly present in the gospels of John or Matthew). This metaphor has been part of the American lexicon since the Colonial era and the Puritan sermons of John Winthrop. It has also been strongly established in U.S. foreign policy discourse (Wander 1984: 339-6). It constitutes a rhetorical model that has its roots in a unique American tradition: the Jeremiad, a form of political sermon favored by the Puritans that relies on what David Campbell calls an "evangelism of fear" and an "evangelism of hope" in order to define the identity and the existence of a community (Campbell 1992: 55). This model has been extensively used by U.S. presidents (Bercovitch 1978, 2012). Ronald Reagan, for instance, famously called the United States "the shining city upon the hill." This has also been true in post-Cold War presidential discourse. America is thus commonly referred to as a "beacon of hope" (1993-01-05; 1994-12-24; 2007-08-28; 2017-10-06) that "lights the world" (2012-07-04) and "a shining example" (1997-09-25; 2017-12-18), opposed to "the dark cloud of war" (2012-05-02), the "dark chaos of dictators" (1991-01-29) and "the darkness" of tyranny (2005-08-30), of fascism, communism (1995-10-06) and terrorism (2017-09-17).

Rhetorically, this binary narrative leaves very little room for any other perspective than the total annihilation of the enemy. Ultimate violence is morally justified by the 
very nature of the enemy, for, as George W. Bush clearly stated, there is "no neutral ground between good and evil" (2004-03-19). It makes wars not only more acceptable but even necessary for the American people. Only violence and war can defeat evil with which there can be no compromise: "a nonviolent movement could not have halted Hitler's armies," argued Barack Obama, and "negotiations cannot convince Al Qaida's leaders to lay down their arms." (2009-12-10) Talking about Daesh in 2014, he declared at the United Nations that "there can be no reasoning-no negotiation-with this brand of evil" (2014-09-24). George W. Bush similarly believed there was "no religious justification" and "no political justification" for the attacks of September 11, 2001 whose "only motivation is evil" (2001-09-25).

This stance proves to be often politically perilous, if not disastrous, as it raises the stakes to the point that America's mission cannot be accomplished. Following 9/11, George W. Bush framed the mission in ambiguous terms: "our responsibility" he said, is to "get the world rid of evil" (2001-09-14). It is not clear whether this was intentional as the final draft of his speech mentioned "this evil" according to Matthew Scully, one of the president's speechwriters (Schlesinger 2008: 463-4). In any case, the president repeated this goal in subsequent remarks, and never recanted (2001-12-20; 2002-01-22). So, the ambition of the task at hand was far greater than what other presidents ventured to say. Even though every president claims that good will eventually overcome evil, they usually tend to offer a more constrained view of America's power: Clinton believed "It is not in our power to rid the world of evil" (1996-03-14), and Obama later reflected that "a world of mortal men and women will never be rid of [...] evil," because "it is God's task" (2008-08-16; 2010-05-22). Donald Trump has also declared "we cannot purge the world of evil or act everywhere there is tyranny" (2018-04-13). This view is not a sign of humility. Rather, it illustrates a policy of troop withdrawal and arguably, isolationism and unilateralism.

The abstract nature of the word "evil" makes it a convenient political tool that can be associated with many things, depending on what the circumstances require. In the post-Cold War era, the word "evil" has been applied as a generic term related to violent acts or totalitarian ideologies that constitute a threat to the world order or to American interests, such as communism (1999-11-08), Nazism (2002-05-24) or radical Islam (2017-01-21), or World War II (1991-01-30; 1994-06-06; 2001-06-06; 2009-06-06, 2019-06-06), the Gulf War (1991-01-29), or the wars in Kosovo (1999-04-05), in Somalia (1993-05-05), in Iraq (2003-01-28), and the fight against Daesh in Syria (2015-09-29; 2017-01-21). More rarely, "evil" may be used to target particular individuals. U.S. Presidents have applied the epithet "evil" to leaders of terrorist organizations such as bin Laden or al-Zarqawi (2006-03-26), rulers of nations or regimes presented as direct threats to world peace such as Saddam Hussein (1991-03-02; 2003-01-28) or Slobodan Milošević (1999-04-05). Labeling them "evil" allows presidents to differentiate these undemocratic leaders from the innocent people under their authority: the enemy is "the Milošević regime," not "the people of Serbia." It is "the oppressor of Iraq," not "the people of Iraq" (2000-10-12; 2001-10-06).

Even though the term "evil" is most often applied to foreign threats, it may also, at times, be applied domestically, in which case it almost always refers to scourges or reprehensible acts of violence that all Americans can unite against. It thus characterizes national sins, past or present, be it slavery (2003-09-23; 2016-02-03; 2019-02-21) or discrimination (1990-10-22), crime (1989-10-30), drugs (1998-06-08; 
2017-10-26), mass shootings (2012-07-12; 2017-10-02) or homegrown terrorism (1995-04-19). Using the term is politically rewarding, as it helps unify the country by providing a religious and moral explanation for deeply rooted social problems while at the same time avoiding more challenging socio-economic reasoning that could threaten the system.

\section{Barbarism vs. Civilization} of the Savage. The Evil Other is first and foremost portrayed as a savage, a being who exists outside civilization, for whom he is a threat. Robert Ivie has demonstrated how images of savagery have permeated the rhetoric of war throughout the nation's history since its foundation (Ivie 1980: 283). Extending the work of Ivie, communication scholar John R. Butler has provided two tropes of savage imagery used to depict America's enemies in presidential discourse: the modern and the primitive savage (Butler 2002).

The primitive savage figure is devoid of all the attributes of civilization and is associated with chaos and the absence of order or state. The primary figure that served as a model to shape America's enemies in foreign policy is the "Indian" of the Old West; it is at the heart of America's oldest and most characteristic myth: that of the Frontier (Slotkin 1993: 10). The primitive savage trope is essentially the story of American progress, with the triumph of civilization over savagery in the settling of the West. As Carney and Stucky have noted, it is not only a marker of national identity. For more than a century, it was associated with the persona of the president, from George Washington (known for his actions in the French and Indian War) to Andrew Jackson (the nation's most famous Indian fighter) and William Henry Harrison and Zachary Taylor (Carney \& Stuckey 2015:165). The modern savages, on the contrary, have a semblance of civilization and a certain "level of cultural sophistication," but are considered uncivilized because of their barbaric actions (Butler 2002: 13). This rhetorical motif was used to depict the British during the War of Independence or the War of 1812 (Ivie 1980: 283).

The two categories have often co-existed throughout American history. In the $20^{\text {th }}$ century, especially during World War II and the Cold War with the growing threat of a more centralized and sophisticated enemy, presidents relied heavily on the figure of the modern savage (Ivie 1980: 283). The collapse of the Soviet Union ushered in a period of dramatic change in the balance of power from bipolarity to unipolarity, defined by George H. Bush as a "new world order." In this confusing new era, presidents returned to a mixed use of modern and primitive savage tropes to define the enemy, depending on their political need and the specific foreign political context (Edwards 2008a).

The consistent underlying narrative has been one of binary opposition between civilization and barbarism, with the enemy placed outside of civilization either by their actions or their nature. Following Saddam Hussein's invasion of Kuwait in August 1990, for instance, George H. Bush told the United Nations General Assembly that "today the [Iraqi] regime stands isolated and out of step with the times, separated from the civilized world not by space but by centuries" (1990-10-01). The Gulf War was then justified because the situation was not "Iraq against Kuwait, but [...] Iraq against the rest of the civilized world" (1990-10-28). America's mission was therefore to lead the 
civilized world or, as Bill Clinton said about Bosnia, "to help the people [...] seek a way back from savagery to civility" (1995-11-29).

21 In the recent decades, terrorism has been the greatest marker of the threat to civilization in presidential rhetoric. Starting in the 1970s, the topic of terrorism gradually gained momentum in presidential speeches as terrorist acts increased in the 1980s, and this continued in the first decade of the post-Cold War period with the rise of non-state threats. Clinton saw terrorism as "an affront to the civilized world" (1996-03-13). The terrorist attacks of 9/11 were the most striking illustrations of this long-established opposition between savagery and civilization in presidential discourse. In a formal address to Congress the week following the attacks, President Bush said: "this is not just America's fight [...] This is the world's fight. This is civilization's fight." (2001-09-20) Paradoxically, by maximizing the stakes, the president acknowledged the claims of the terrorists that they were waging jihad against the West. It is also in this speech that the war against terrorism or against Al-Qaeda became the "war on terror." The semantic shift from "terrorism" to "terror" entertained the confusion between actor, action and effect, and the use of the preposition "on" instead of "against" reinforced the abstract nature of this new kind of war (Nunberg 2004). It was a war defined as "a war to save civilization itself" (2001-11-08). The president started his 2002 State of the Union address by stating that the civilized world faced unprecedented dangers, conflating the regimes in the "axis of evil" with "terror". Bush was then able to target the Iraqi regime for having "weapons of terror" and "something to hide from the civilized world" (2001-01-29). This view became prevalent after 2001: Obama talked about the "savagery of the terrorists" (2010-11-06), and Donald Trump claimed that the terrorists were "engaged in a war against civilization," and that, as a result, "civilization is at a precipice" (2017-05-26).

At the same time, by contrasting civilization and savagery, American presidents have rejected, often explicitly, the idea of a clash of civilizations, a hypothesis developed by political scientist Samuel P. Huntington in the 1990s and popular in some circles. His controversial conjecture was that the post-Cold War idea would be characterized by conflicts between groups of countries with shared cultural and religious identities (Huntington 1993). Bill Clinton was the first president to dismiss the idea at a UN General Assembly: "many believe there is an inevitable clash between Western civilization and Western values, and Islamic civilizations and values. I believe this view is terribly wrong" (1998-09-21). Similarly, George W. Bush was also explicit: "there is no clash of civilizations," he said, adding that "the requirements of freedom apply fully to Africa and Latin America and the entire Islamic world" (2002-06-01); Barack Obama called it "a lie" (2015-02-19) and "propaganda" (2009-06-01). Donald Trump has been more ambiguous. On the one hand, he has embraced the idea of his predecessors that the fight against terrorism is "not a battle between different faiths, different sects, or different civilizations" but a "battle between barbaric criminals who seek to obliterate human life and decent people, all in the name of religion. People that want to protect life and want to protect their religion. This is a battle between good and evil." (2017-05-21) On the other hand, he clearly evoked the threats facing Western civilization several times in a speech in Poland, asking "whether the West has the will to survive" concluding with a strong statement: "I declare today for the world to hear that the West will never, ever be broken. Our values will prevail. Our people will thrive. And our civilization will triumph" (2017-07-06). This was naturally meant to please a nationalist religious-conservative audience both in Poland (where the audience 
chanted "Donald Trump") and in the United States. This is also unsurprising from a president who owed his election in part to declarations that he wanted a "complete shutdown of Muslims entering our country" (2015-12-7) and that "Islam hates us" (2016-03-09) during his campaign. Otherwise, Donald Trump's use of the binary narrative of a clash between civilization and savagery has been rather conventional, mostly reserved to World War II commemorations.

\section{The Primitive Savage}

The dichotomy between the "primitive" and the "modern" savage is helpful for both political and rhetorical analysis of presidential discourse, but it is not necessarily always an exact one. An enemy can sometimes be deemed both "modern" and "savage" by presidents. Saddam Hussein is the best illustration of this dual rhetorical construction: he was sophisticated enough to constitute a threat to civilization, but he was also "the perfect enemy for a Frontier-Myth scenario" (Slotkin 1993: 651). When he took Americans hostage after growing tensions with the Bush administration in the summer of 1990, his appearance on television with Western hostages, especially with a young British boy on his lap as propaganda, reinforced the symbolism of innocent white victims at the hands of a savage evil other. His action was deemed "barbaric" (1990-09-16), and, as historian Richard Slotkin observed, George H. Bush eventually invoked the classic elements of "captivity" and "savage" war mythology to justify the deployment of the largest American military force since the Vietnam war. 
Figure 2. TV footage of Saddam Hussein with a 5-year-old British hostage on 24 August 1990

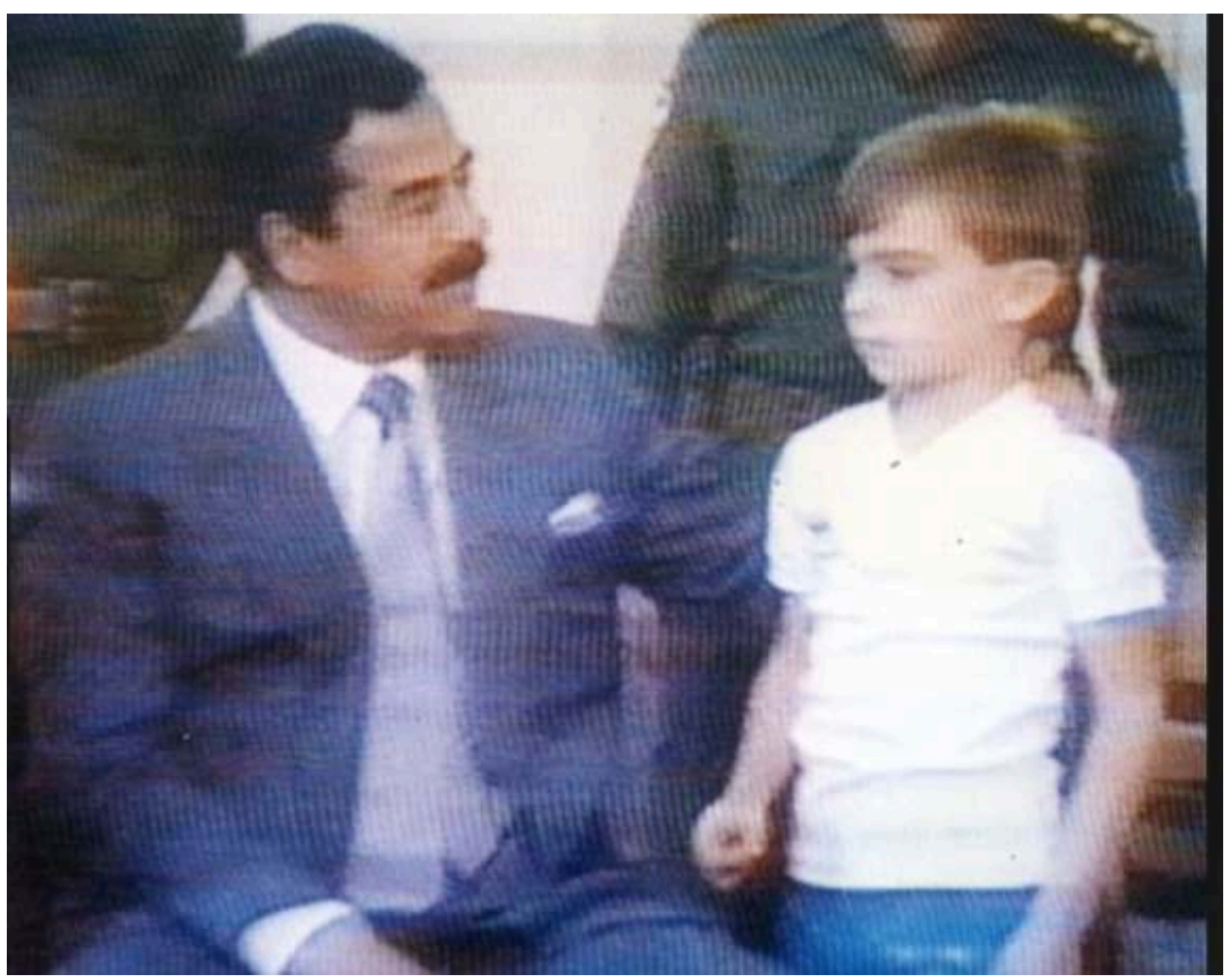

Source: https://www.dailymail.co.uk/news/article-1165186/British-child-hostage-refused-sitSaddams-knee-reunited-rescuer-Jesse-Jackson-19-years-ordeal.html. See also https:// www.theguardian.com/artanddesign/2015/jun/05/thats-me-picture-stuart-lockwood-saddamhussein-iraq

This narrative constitutes what communication scholar Robert L. Ivie calls a "decivilizing vehicle" (2005: 46). To create the image of the enemy as a savage outside civilization, presidents and their speechwriters employ powerful images and rhetorical conduits, essentially clusters of metaphors that frame the tenor (the subject of the metaphor) as uncivilized and subhuman. Dehumanizing the enemy is a classic strategy to make counter-violence more acceptable. Enemies are, for instance, often portrayed through animal imagery. Talking about the new threats following the collapse of the Soviet empire, George H. Bush thus warned: "the Soviet bear may be extinct, but there are still plenty of wolves in the woods," adding that "this President will never allow a lone wolf to endanger the security of the United States of America." (1992-08-25) Following 9/11, the term "lone wolf" would be associated with lone-actor terrorists (2004-10-07; 2013-09-09; 2015-07-06). Terrorists also "prey upon young impressionable minds" (2015-02-19) and the "frustrations of people" (04-01-2008). They "cower in caves" (2010-09-11) where they "burrow deeper" (2001-10-07) and they must be "hunted down" (2002-09-16; 2015-01-20). Hunt vocabulary is particularly prevalent in George W. Bush's rhetoric: You not only "hunt them down," you also "get them running," and "smoke them out of their holes" (2001-09-16), promising to stay "on the hunt"-an expression used by Bush in more than one hundred speeches during his presidency. These are tropes that also belong to the Frontier motif: smoke was used to combat vermin (West \& Carey 2006: 386-7). The terrorists that were hiding in so-called "rogue states" were compared to "parasites" that want to "take over the host" (2004-09-20) or "leech onto a host country" (2001-10-21). 

discourse. Addressing the nation to announce military action in Panama, George $\mathrm{H}$. Bush justified the action by accusing Manuel Noriega not only of the death of Americans but also of "beating up" an American serviceman and then "brutally interrogat[ing] his wife, threatening her with sexual abuse" (1989-12-20). Using the common conceptual metaphor of the "nation-is-person," the American president similarly blamed Saddam Hussein for the "ruthless, systematic rape of a peaceful neighbor" (1991-01-29), making it clear that the rape of Kuwait was not just metaphorical. "On August $2^{\text {nd }}$, Iraq invaded Kuwait," he insisted, "they literally literally, not figuratively - literally raped, pillaged, and plundered this once-peaceful land" (1990-11-04). Other presidents have asserted that the enemy-as-a-rapist was to be taken literally. Clinton, G.W. Bush, and Obama all accused different enemies of using rape as a political weapon: Milošević "rape[d] wives and daughters to intimidate people" (1994-09-14), and "sent the soldiers" that raped children (1999-04-24); Saddam Hussein had "rape rooms" and used rape as "method of intimidation" (2002-10-07; 2003-03-17); and Lybian leader Muammar Qadhafi used "rape as a weapon of war" (2011-06-29).

Other graphic accounts of atrocities reinforce the sense of lawlessness, violence and lack of control characteristic of savages. They are likely to trigger a desire for the restoration of control and order in the audience on humanitarian grounds and make military interventions more acceptable. Following the invasion of Kuwait by Saddam Hussein in August 1990, President Bush stated that what was at stake was the "new world [...] struggling to be born, [...], a world where the rule of law supplants the rule of the jungle." (1990-09-11) Similarly, the justification for intervention in Somalia was the breakdown of "law and order", the prevalence of anarchy, illustrated by "armed gangs roving the city" (1992-12-04). In the post-Cold War era, the greatest threat to the United States did not seem to be nation-states but rather global chaos (Edwards 2008a: 841). Bill Clinton framed what was at play in the world at the dawn of a new millennium as a "battle of the forces of integration against the forces of disintegration, of globalism versus tribalism" (1999-04-12a), with the United States set apart by the fact that it "will not be destroyed by the racial, religious, ethnic, and tribal tensions that are tearing the rest of the world up" (1996-08-08). One way to fight lawlessness is to bring civilization. The building of a new highway in Afghanistan, for instance, was presented as a way to "weaken the grip of the warlords" (2003-05-23). As Carney and Stuckey observe, the use of words such as "warlords," "tribal" and "tribalism" in presidential speeches denotes "primitive forms of political organization inside of underdeveloped territories only sporadically controlled" that are reminiscent of the Indian in the Frontier myth (Carney \& Stuckey 2015: 173). a more detailed rhetoric of atrocities. A few days before launching Operation Uphold Democracy, a military intervention in Haiti in September 1994, President Clinton described General Raoul Cedras's regime as "the most violent regime in our hemisphere" whose "armed thugs have conducted a reign of terror, executing children, raping women, killing priests" (1994-09-15). As U.S. troops were sent to the Gulf region to prepare for a likely conflict with Saddam Hussein, George H. Bush told the story of "dialysis patients [...] ripped from their machines" and "Iraqi soldiers pull[ing] the plug on incubators supporting 22 premature babies who all died," with "hospital employees 
[...] shot and the plundered machines [...] shipped off to Baghdad" (1990-10-28). Variants of these stories were repeated between October and November 1990. They eventually turned out to be false claims concocted by a lobbying firm hired by the Kuwaiti government (Ben-Porath 2007: 189). ${ }^{3}$ Talking again about the Iraqi regime, George W. Bush also gave detailed accounts of the savagery of Saddam Hussein and his regime with stories of dissidents being "tortured, imprisoned [...] their hands, feet, and tongues [...] cut off; their eyes [...] gouged out" (2003-03-15). In the same manner, Barack Obama gave gruesome descriptions of the gas attacks perpetrated by Bashar alAssad's regime in 2013 in order to convince his war-fatigued nation of the legitimacy of strikes against Syrian troops: "Men, women, children lying in rows, killed by poison gas. Others foaming at the mouth, gasping for breath. A father clutching his dead children, imploring them to get up and walk" (2013-09-10).

In his study of the presidential rhetoric of atrocities, communication scholar Eran R. Ben-Porath concludes that narratives of atrocities are the most prominent manifestation of the savagery trope employed by presidents in arguing their case for war in the post-Cold War era (Ben-Poath 2007: 183, 197). In many cases then, Presidents seem to use these detailed accounts of scenes of atrocities to compensate for the lack of clear and imminent danger or the fear of ideological dominance as a justification for war. False propaganda based on fake stories was all the more credible as it was mixed with authentic accounts of Saddam Hussein's regime of crime and terror.

But this strategy sometimes backfires, especially when it concerns American casualties. The outcry following the images of the bodies of American soldiers dragged through the streets of Mogadishu in October 1993 led Bill Clinton, two days later, to try to justify military intervention with the fear of a return to "anarchy, mass famine" and "chaos" (1993-10-07), although he eventually had to scale down U.S. involvement in the region.

\section{The Modern Savage}

30 The moral matrix of all modern wars is the World War II. In presidential rhetoric, it is the framework of a morally justifiable war waged by the civilized world, often referred to as "the good war." According to historian David Noon, the sacred status of World War II has only been enhanced since the implosion of the Cold War (Noon 2004: 343). It has been also constantly referred to by presidents, not only because World War II commemorations have multiplied but also because it has become the analogy favored by presidents to explain the present, and to justify their actions and policy. In this paradigm, Adolf Hitler is the ultimate model of the evil modern savage.

31 Iraq's invasion of Kuwait was thus compared to a blitzkrieg (1990-08-08). Then, the launching of the Gulf War was justified by the lesson from the past: "the world had ignored the brewing madness 50 years ago. We would not make the same mistake this time" (1991-06-06). And when both presidents Bush went to war, they criticized diplomatic concessions with dictators and the words "appease" and "appeasement" by using the Munich analogy, referring to the 1938 Munich Agreement with Hitler (2003-03-17). This analogy has not only been applied to Saddam Hussein. Bill Clinton described the refugee camps in Bosnia by calling to mind pictures of World War II concentration camps (1995-11-27). He also drew parallels between Milošević and Hitler: ethnic cleansing in Kosovo was presented as the result of "the 10-year method of Mr. Milošević 's madness," (1999-06-02) and his "pattern of perfidy" (1999-04-12a), a typical 
feature of the modern savage, a more sophisticated and centralized enemy, capable of planning (Butler 2002: 14). In reality, Milošević was very different from Hitler, notably because he did not threaten the entire European continent, but Clinton defended America's involvement in Bosnia and Kosovo by concluding that this time "our people will not be called to fight a wider war for someone else's madness" (1999-04-12b). George W. Bush also described the terrorists who attacked the nation on 9/11 as "heirs of [...] Fascism and Nazism" (2001-09-20). By the end of his second term, he dismissed critics of the war on terror by accusing them of propagating the "false comfort of appeasement which has been repeatedly discredited by history" (2008-05-15) The idea that terrorists advocate an evil ideology, also recently used by Donald Trump regarding ISIS (2017-04-05), implies that the terrorists have the ability to theorize a long-term vision and possess a highly developed level of abstraction. By making allegations of "high-level contacts" between Al Qaeda and Iraq in "planning for chemical and biological attacks", accusing Iraq of training "Al Qaeda members in bomb making and poisons and deadly gases," George W. Bush associated the terrorists with sophisticated schemes, thus exaggerating their strength as well as building a case for the 2003 invasion of Iraq (2002-10-07). Indeed, if the danger posed by the primitive savage is limited in scope, a modern savage can constitute a greater threat to the United States and to the world.

Hitler is not the only model of the modern savage. Presidents have sometimes resorted to figures more uniquely American that evoke the Frontier myth. For instance, the word "outlaw" has been used to label a number of leaders and regimes: Noriega (1989-09-01), Saddam Hussein (1990-12-24; 1993-06-26; 2003-03-19) and North Korea (2017-09-26). According to the American Heritage dictionary, it is a word that "brings to mind the cattle rustlers and gunslingers of the Wild West." ${ }^{4}$ Here again, it is by his action of breaking the law that the outlaw steps out of civilization, whereas the primitive savage is by his own nature outside civilization. These unlawful acts are so threatening to the social order or the world order that they must be met with a special form of quick justice typical of the Old West. As president Bush said about Osama bin Laden, only six days after the 9/11 terrorist attack: "I want him held-I want justice. There's an old poster out West, as I recall, that said, 'Wanted: Dead or Alive."' (2001-09-17). It is the same justice that is conjured up by the image of the hangman's "noose". "We're slowly but surely tightening the noose," claimed George W. Bush about Al Qaeda (2001-11-07), an expression also used by Barack Obama for "Bashar al-Assad and his cohorts" (2012-03-13), or about Qadhafi (2011-03-11).

The image of the "modern savage" makes the adversary powerful and sophisticated enough to pose a threat to the existence to America's national interests, if not to civilization itself. In other words, it is a narrative tool to create an enemy worthy of America's heroic status, and the narrative is meant to conclude with the surrender of the enemy. The collapse of the Soviet empire raised hopes of a "new world order" based on permanent peace and prosperity, though in reality it gave rise to a period of perpetual war characterized by conflicts with no victory. As President Trump affirmed at CIA headquarters in January 2017,

When I was young, we were always winning things in this country. We'd win with trade. We'd win with wars. At a certain age, I remember hearing from one of my instructors, 'The United States has never lost a war.' (Remarks at the Central Intelligence Agency in Langley, Virginia, January 21, 2017.) 
fourse, the United States has lost wars in the past, even if the blame is commonly put on politicians and weak leadership rather than the military who fought "with one hand behind their back" (1991-01-16). In fact, the victory of the Gulf War was also presented by Bush as a way to kick "the Vietnam syndrome once and for all" (1991-03-01). But it was, at best, a very incomplete victory that built up frustration by allowing a man once compared to Hitler and defined as evil to remain in power. The dissonance between the rhetorical construction of the enemy and the reality on the ground is a major feature of the post-Cold War era. It only became more pronounced after 9/11, with the War on Terror, the war in Iraq and Afghanistan, none of which brought victory or a sense of a "mission accomplished". The result has been the nation's growing war fatigue. This led in part to the election of President Obama and a "shift away from a perpetual war footing" (2013-09-24), but also to the failure to consider the dangers posed by new threats, such as the rise of Daesh in Syria.

\section{A Close(r) Enemy}

Despite an occasionally dangerously chaotic and bellicose rhetoric, Donald Trump has not actually changed course, and has not, so far, engaged the United States in any new war, even advocating for troop withdrawal (2018-12-26). What has changed, however, is his rhetorical construction of America's enemy. His discourse has focused, for the most part, on building a new kind of enemy posing a more immediate and palpable threat, located both inside and right across the country's border. This does not mean that foreign enemy nations have completely vanished from presidential discourse, but the president's rhetoric against Iran, Venezuela or North Korea has not reached the level or frequency of the animosity employed against perceived domestic threats. This has been particularly true of immigration, which has been repeatedly depicted through war metaphors. It has been deemed an "invasion" (2018-05-08), while Immigration and Customs Enforcement (ICE) agents have been called "warriors," and the fight against illegal immigration has been described literally as "fighting a war" (2018-08-02), as troops have been sent to the border "to defend our very dangerous southern border" and "protect our homeland" (2019-02-05). But this war is also being fought on U.S. soil, as his reference to an "American carnage" made clear in his Inaugural address (2017-01-20). In this narrative, he has played the heroic role of the liberator:

And the towns - this is Long Island, where I grew up. You have the same kind of communities. But, for some reason, so many in Long Island - it's like they've been liberated, like from a war. It's like the enemy has been taken out and the people are dancing and they're waving and they are looking out their windows and they are waving to the ICE people. Those people are incredible, brave, tough people. They've been liberated. (Donald Trump Holds a Political Rally in Nashville, Tennessee, May 29, 2018)

Using war rhetoric for domestic issues is hardly novel. Crime has often been understood through the war metaphor and the "war on drugs" is a common way to frame the fight against illegal drugs (De Durand 2002). These war metaphors encourage a mystique of violence as a way to solve social problems. They highlight the punitive aspect, implicitly excluding other solutions such as treatment, and lead to harsh policies. There have always been scourges or reprehensible acts of violence that all Americans could be united against. The difference with previous uses of the war metaphor is that Donald Trump's rhetoric no longer targets consensual social 
afflictions but rather partisan issues such as guns and abortion and specific groups of people, such as the media or immigrants. In Trump's rhetoric, every political issue is framed through the rhetoric of war: climate change is about "war on beautiful, clean coal" (2017-04-29), religious liberty is being "destroyed" (2017-07-12), and the president has "led the charge against the assault on Christmas," ending the "eight-year assault on [the] Second Amendment" (2017-04-28). Even his economic policy has centered on "trade wars [that] are easy to win" (@real Donald Trump, March 2, 2018, 6:50 pm EST).

Instead of going abroad "in search of monsters to destroy," to use John Quincy Adams's phrase, the president is now essentially looking for monsters at home, mostly to satisfy his electoral base in an increasingly polarized nation (Adams 1821).

For the war metaphor to be effective, an enemy must be clearly identified. Donald Trump has constructed a number of enemy figures by applying the traditional enemy imagery used by his predecessors to new targets: from immigrants to his political opponents and the news media. But he has also been explicit, especially regarding the press, calling them "enemies of mine" and eventually "enemies of the American people."

Figure 3. Tweet by Donald Trump attacking the press as "Enemy of the people" on April 5, 2019

\section{Donald J. Trump}

@realDonaldTrump

The press is doing everything within their power to fight the magnificence of the phrase, MAKE AMERICA GREAT AGAIN! They can't stand the fact that this Administration has done more than virtually any other Administration in its first 2yrs. They are truly the ENEMY OF THE PEOPLE!

\section{K 7:41 PM - Apr 5, 2019}

The irony is that the expression "enemy of the people" was the favorite designation for political opponents in authoritarian regimes, one used especially by Joseph Stalin in the Soviet Union (Kalb 2018: 24). Trump sometimes names these enemies, with CNN, NBC and the New York Times being his favorite targets: 
Figure 4. Tweet by Donald Trump attacking major U.S. press outlets as "enem[ies] of the American people" on February 17, 2017

Donald J. Trump

@realDonaldTrump

\section{Suivre}

\section{The FAKE NEWS media (failing @nytimes, @NBCNews, @ABC, @CBS, @CNN) is not my enemy, it is the enemy of the American People!}

13:48 - 17 févr. 2017

48050 Retweets 148447 J'aime 8 (3) 8 (2) 8 (i)

But often he merely uses the blanket term "fake news" to fend off accusations of attacking the media and the press, and to play the victim. Thus, at the Conservative Political Action Conference (CPAC) in February 2017, he argued:

They're very dishonest people. In fact, in covering my comments, the dishonest media did not explain that I called the fake news the enemy of the people. The fake news. They dropped off the word "fake." And all of a sudden, the story became the media is the enemy. (Remarks at the Conservative Political Action Conference in National Harbor, Maryland, February 24, 2017)

President Trump has also made partisan use of the word "evil":

That Washington, D.C. - have a lot of evil there, but we are getting it out, step by step - a lot of evil, a lot of bad people, a lot of fake media. Look at them - a lot of fake media, fake, fake media." (Remarks at a "Make America Great Again Rally" Moon Township, Pennsylvania, March 10, 2018)

Democrats, as well as Republican Senator John McCain or the team lead by Robert Mueller to investigate Russian interference in the 2016 U.S. presidential election, have all been referred to by Trump as "evil", doing "treasonous things against our country" (2019-03-25). Using the term "evil" as a domestic political tool has been so remarkable that a reporter had the following exchange with the president over his choice of words:

Q: Mr. President, what about your comment yesterday that some of these forces against Brett Kavanaugh [Trump's nominee for Supreme Court Justice] were, quote, "evil"?

The President: Yes, I think they were. I think they were. Yes.

Q: You mean "evil." When you say "evil," you mean evil?

The President: Yes, I'm not going to say who I mean. I'm just telling you, you had forces saying things that were evil. They were bad people. [...]

Q: But should we say that about our fellow Americans?

The President: I know many. I know fellow Americans that are evil. I know-are you saying we shouldn't say that a fellow American is "evil"? I've known some fellow Americans that are pretty evil. (Remarks in an Exchange With Reporters Prior to Departure for Council Bluffs, Iowa, October 09, 2018)

Such symbolic violence, to use Bourdieu's term, is nothing new. As historian Richard Slotkin has shown, it is not so much violence itself, but the mythic significance it has been given in American culture and politics that is uniquely American (Slotkin 1993: 13). What makes Donald Trump's discourse distinct from that of his predecessors, at 
least in the modern era, is not his reliance on rhetorical violence but rather the transformation of political rivals and critics into enemies. It suggests, at least to his supporters, that, just like terrorists or foreign dictators, political rivals or critics must be completely destroyed, and that no compromise is possible. This in turn increases partisanship and polarization.

of course, Donald Trump did not start this process. In his study of the "politics of resentment" in the United States, Jeremy Engels traces divisiveness in presidential rhetoric back to the presidency of Richard Nixon (Engels 2015: 28). However, no other president has been so consistent, driven, and unequivocal in relying on constant antagonism and disruption. This may make it more difficult to govern in a two-party system that relies on compromise to function, but that does not necessarily concern a president who has focused more on campaigning than governing, both in style and strategy.

Essentially, Donald Trump's enemy construction has been consistent with his predecessors in the sense that he has also largely relied on the trope of the savage. This is evident in how he has talked about immigrants. His remarks announcing his candidacy famously made the headlines precisely for his very negative depiction of Mexican immigrants:

When Mexico sends its people, they're not sending their best. [...] They're sending people that have lots of problems, and they're bringing those problems with us. They're bringing drugs. They're bringing crime. They're rapists. And some, I assume, are good people. (Remarks Announcing Candidacy for President in New York City, June 16, 2015)

Conflating terrorists, criminals and illegal immigrants, Donald Trump has focused on a savage enemy, "the predators and criminal aliens who poison our communities with drugs and prey on innocent young people" (2017-07-25), particularly the "savage gang MS-13 and its bloodthirsty creed, 'Kill, Rape, and Control"' (2018-06-22). In one of his first executive orders as president, Donald Trump portrayed the illegal immigrant as "a significant threat to national security and public safety," capable of "acts of terror or criminal conduct" and a "clear and present danger to the interests of the United States" (2017-01-25). In order to make this threat more immediate, he relied on a number of rhetorical tools to turn undocumented immigrants into modern day savage Indians.

Like the Indians in the Frontier myth, undocumented immigrants are both inside and outside of U.S. territory, and their enemy image is built on conflation and exaggeration (Carney \& Stuckey 2015). Just like all natives were treated as enemies during the Indian Wars, "illegal immigrants" are treated as a single undifferentiated mass, despite their various origins, situations, and motivations, and they are conflated with crime, drugs and violence. They have "caused tremendous crime [...] murdered people, raped people," the president has argued (2017-04-18). He has constantly associated them with the MS-13 gang through horrific descriptions of acts committed by the gang, which he refers to as "animals [...] preying on children" (2017-12-08). Just as with Indians in the Frontier myth, illegal immigrants may be "primitive savages" but they constitute a national threat nonetheless through deception and trickery (Carney \& Stuckey 2015). Trump thus warns the American people that immigrant children have "exploited the loopholes in our laws to enter the country as unaccompanied alien minors. They look so innocent; they're not innocent" (2018-05-23). And each one carries the risk of more 
since the president has claimed that "a single immigrant can bring in virtually unlimited numbers of distant relatives" (2018-01-30) and put "great strain on Federal welfare" (2017-12-16).

As Richard Slotkin has shown, in the heroic tale of the Frontier, the victimization of the white settlers served to alleviate any guilt that might have existed regarding the treatment of the natives (Slotkin 1993: 113, 144). This is part of a greater trend among conservatives who feel victimized. Jeremy Engels notes that "the claim to victimhood and the accusation that political opponents are victimizers are common to the key tropes of conservative discourse today" (Engels 2015: 153). In Trump's discourse, the function of victimization is to make immoral immigration policies more acceptable. Kenneth Burke has called it the "rhetoric of victimage," that is to say a form of scapegoating to redeem one's guilt (Burke 1968). Even if Donald Trump has occasionally mentioned immigrant women and children as victims of human trafficking (2019-01-10), the president has mostly focused on American victims killed by illegal immigrants, referring to the mothers of these victims as "Angel Moms" (2019-02-15). Only two days after signing an executive order that would end the forced separation of detained immigrant family members, Trump staged a meeting for the American families of victims killed by illegal immigrants who were presented as double victims (2018-06-22). First, because "these are the American citizens permanently separated from their loved ones," adding without much subtlety, "the word 'permanently' being the word that you have to think about - permanently. They're not separated for a day or two days. These are permanently separated, because they were killed by criminal illegal aliens." Secondly because "these are the families the media ignores. They don't talk about them. Very unfair" (2018-06-22). This victimization must be understood against the backdrop of a gruesome narrative of a nation at war on its own soil. Communities "under siege" (2018-04-18) by a "ruthless gang [MS-13] that has violated our borders" (2018-05-23), using Trump's favorite example of a criminal organization supposedly made up of foreigners. In this new version of the Frontier myth, the heroic cavalry liberating the captives is embodied by the Immigration and Customs Enforcement service (ICE).

Figure 5. Tweet by Donald Trump attacking Democrats and defending ICE on June 30, 2018

Donald J. Trump

@realDonaldTrump

The Democrats are making a strong push to abolish ICE, one of the smartest, toughest and most spirited law enforcement groups of men and women that I have ever seen. I have watched ICE liberate towns from the grasp of MS-13 \& clean out the toughest of situations. They are great!

105K 1:07 PM - Jun 30, 2018

This stance is rooted in the classic "captivity-and-rescue" narrative of the Frontier myth. In this version, Donald Trump is the ultimate solitary, heroic figure. Just like George W. Bush, Trump evoked the Old West by referring to a special form of quick 
justice outside the law, referring to potentially illegal immigrants rather than a foreign enemy such as Bin Laden:

They'll go through court for years, and at the end, they'll be - who knows what happens. We need quick justice and we need strong justice - much quicker and much stronger than we have right now. (Remarks: Donald Trump Attends a Cabinet Meeting, November 1, 2017) enemy is perceived as fluid. Along with the image of a nation under siege, it relies on the nation-as-a-container metaphor, a conceptual metaphor that helps demarcate an "inside" from an "outside", "self" from "other", "domestic" from "foreign". This perception is illustrated by the way the president frames the issue of immigration by using liquid metaphors: illegal immigration has "surged," and refugees have "flooded in" (2017-04-29), The caravan is pouring up to the U.S. (2018-10-31b), millions of people are already flowing through Mexico (2019-06-04) in a "massive surging flow that must be stopped" (2019-03-13), while Democrats are accused of throwing the floodgates wide open (2019-10-17). And he makes it clear that the container is full:

[They] fill up and our hospitals, schools and public resources overburdened. Our country is full, we don't want people coming up here. Our country is full. We want Mexico to stop, we want all of them to stop. Our country is packed to the gills. (Donald Trump, Political Rally in Montoursville, Pennsylvania, May 20, 2019)

This warrants the construction of a "flood" wall and the implementation of a restrictive immigration policy, the wall being the "bounding surface" that is used to mark off the territory of the container. But the wall is not simply a symbol of exclusion but also of purity (Richardson 2017: 747).

Donald Trump has also drawn parallels between rape and the invasion of a nation by illegal aliens who "violate our borders" (2018-10-31a), even giving graphic details of "women tied up, bound, with duct tape put around their faces, around their mouths, in many cases they can't even breathe. They're put in the backs of cars or vans or trucks." (2019-01-25) This bodily metaphor is likely to activate particularly strong feelings in a more conservative or nationalist audience that tends to have a more gendered worldview focused on power and strength (Viala-Gaudefroy 2019).

nation-as-a-body metaphor, a variant of the container metaphor, is commonly used in the English language and in foreign policy discourse (Musolff 2010). It is the conceptual metaphor used by George H. Bush when he talked about the "rape of Kuwait" in 1990. But the closer the body, the more emotionally powerful this metaphor is likely to be (Gregg 2004: 59). One of the strongest emotions resulting from the idea of things and creatures coming inside and violating boundaries is disgust (Miller 2017:14). According to communication scholar Michael Richardson, disgust is one of the primary affective drivers of Trump's political success, not only because of the disgust he expresses but also because he is himself an object of disgust to his critics, which, only reinforces his appeal for his supporters (Richardson 2017).

Donald Trump has steadily relied on a vocabulary linked to bodily functions, cleanliness or dirt to describe threatening Others. During his campaign, he referred to journalist Megyn Kelly's menstruation, Democratic presidential nominee Hillary Clinton's toilet behaviors, Republican Senator and rival Marco Rubio's sweating or Republican rival John Kasich's eating as "disgusting" (Hall et al. 2016: 82). He has made great use of adjectives such as "filthy," "dirty" and "ugly", and has repeatedly vowed to "clean up Washington" and "drain the swamp [i.e. the Washington political 
establishment]." This abundant vocabulary of disgust is greatly reinforced by his gestures, facial expressions and the way he carries his own body. More than any other president, Donald Trump embodies his words. His success depends greatly on comedic representations of his political opponents as well as himself (Hall et al. 2016: 73). Disgust is also associated with immigrants through the use of animal metaphors, a traditional ploy in anti-immigrant discourse. Usually these are animals considered of the lower orders such as rats, snakes, insects, parasites or vermin. For instance, Donald Trump has often illustrated his view on immigration by telling a story called "The Snake", which he has given countless times at his supporters' rallies during the campaign and since taking office. He teases his audience: "But when I walked in today, did anyone ever hear me do the snake during the campaign? Because I had five people outside say, "Could you do "The Snake'?" at which the crowd always cheers and claps (2018-02-23). Trump refers to the lyrics based on a rock 'n roll song and is not shy about the message: "you have to think of this in terms of immigration," he said. The story is about a snake, freezing in the cold, "his pretty colored skin, frosted". The snake persuaded a woman to take him into her house. She saved him and comforted him. But "instead of saying thank you, that snake gave her a vicious bite. 'And you've bitten me. Heavens why? You know your bite is poisonous, and now I'm going to die.' Oh, shut up, silly woman,' said the reptile with a grin. 'You knew damn well I was a snake before you took me in."”

Figure 6. Video of Donald Trump doing "the snake" at Conservative Political Action Conference (CPAC) on February 23, 2018

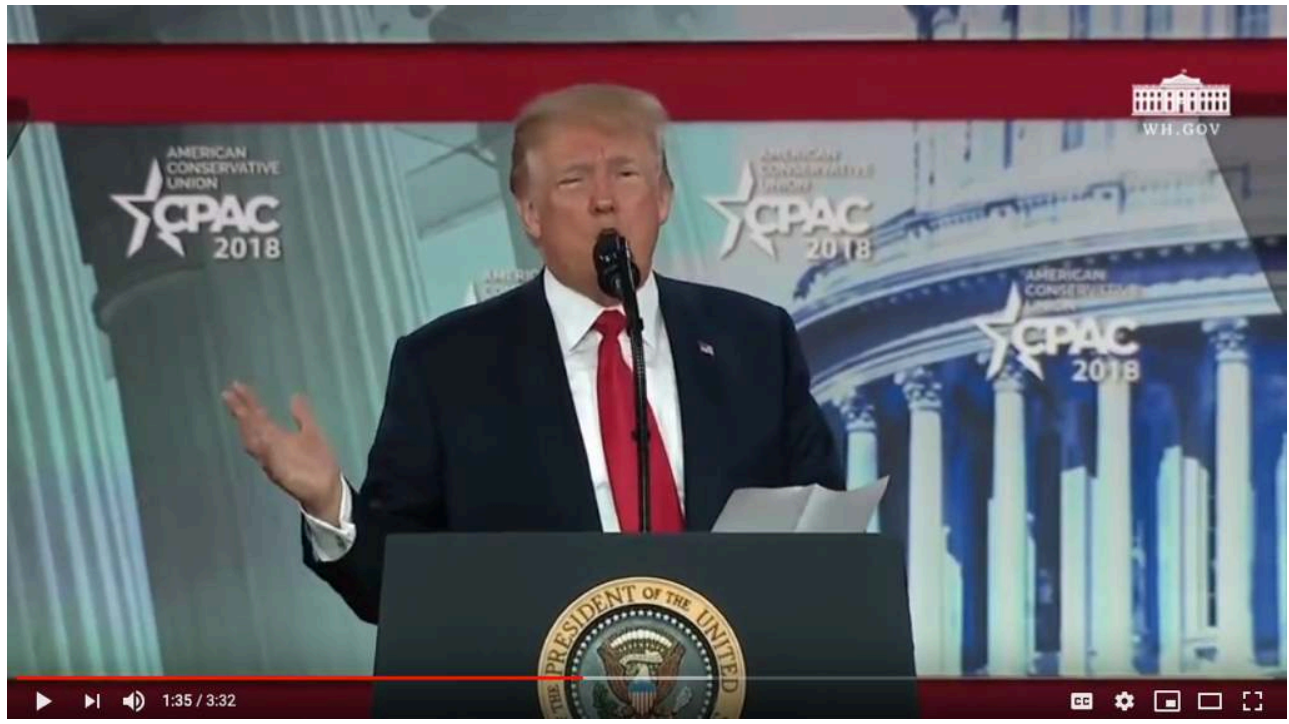

Source: https://www.youtube.com/watch?v=SwC8obW2DMg

This allegory is meant to show that all immigrants - not just undocumented ones - will end up hurting their host country because they are like a "reptile with a grin" who will take advantage of their host and act like parasites, connecting immigrants and disgust, which is in line with his supporters' views. A global study by Yoel Inbar, David Pizarro, Ravi Iyer and Jonathan Haidt has shown that subjects with a low threshold for disgust are more likely to be conservative in political orientation (Inbar 2012).

Donald Trump has thus constructed a discursive enemy image by using the familiar trope of the savage and war metaphors. The novelty lies in that it is his political rivals 
and the news media that play the role of the modern savage in his narrative, and immigrants who are the primitive savage. As we have seen, he has also relied heavily on his ability to express disgust and resonate with the anti-immigrant, anti-establishment sentiment of his audience. The two categories of savages remain relevant: the primitive one is disgusting by nature, and the modern one is disgusting by his (or mostly her) behavior.

\section{Conclusion}

The enemy image in U.S. presidential discourse is shaped by two distinctively American features: the myth of the Frontier, and the fusion of moral and religious beliefs rooted in the Puritan era. Its main function is to give a dramatic and binary structure to the national narrative and constantly renew the national identity by providing a counterpoint for the Self: the Evil Savage Other. This savage Self is an indispensable confirmation of how virtuous, good and civilized the Self is. Since the end of the Soviet empire, the United States has been missing an enemy worthy of itself, capable of giving it a renewed sense of victory. This is what prompted Bill Clinton to say how much he missed the Cold War and its easily workable framework. The end of the Cold War was thus characterized by a return to both the primitive and modern savage images in presidential rhetoric, sometimes even for the same enemy, depending on the political situation. As a vital rhetorical component of war rhetoric, the labeling of the Other as an enemy has enabled presidents to channel aggression outwards. By constructing the image of the enemy as a savage outside civilization, they have refuted the idea of a clash of civilizations. For America and its allies, U.S. presidents have promoted a rhetoric of universal sameness, common values and aspirations and everlasting economic expansion. With the Soviet empire gone, the entire world became the new Frontier, a world that could be remade in America's image. This was George H. Bush's "New World Order," Bill Clinton's "common humanity" and "market democracies," George W. Bush's extension of the "frontiers of freedom," and to some extent, Barack Obama's doctrine of negotiation and collaboration based on shared risk, collective wisdom, and unity. As it turns out, the paradigm of "shared values" and boundless prosperity did not deliver its promise. The 2008 economic crisis, along with international terrorism, religious radicalism, migration and demographic changes only precipitated the rejection of the rhetoric of sameness and resulted in a renewed sense of cultural and identity appropriation.

Donald Trump's nativist discourse expresses his rejection of this paradigm. His obsession with borders, the wall and immigrants are the negation of the Frontier narrative of openness and unlimited expansion. The newfound enemy illustrates the new paradigm of a nation as a "besieged medieval fortress, with its own revered martyrs' cult" (Grandin 2019: 232), a narrative that also echoes the view of many evangelicals. Trump's neo-mercantilist economic philosophy of zero-sum games and trade wars means that, in the words of Trump's national security advisor, Lt. Gen. H. R. McMaster, and the director of the National Economic Council, Gary Cohn, the world is no longer a "global community" but "an arena where nations, nongovernmental actors and businesses engage and compete for advantage." (McMaster \& Cohn 2017) As historian Greg Grandin recently concluded, the election of Donald Trump may signify that "American finds itself at the end of its myth" (Grandin 2019: 13). 
59 As a result, the recognition of limits does not challenge capitalism, but requires capitalistic and identity domination. This may be part of the appeal of Trump's antiimmigration rhetoric to some Americans. Trump's refusal of limits and restraints for himself pleases his electoral base who believe that American freedom is essentially the lifting of restrictions on their ability to express themselves, own guns or defend their racial and religious identity, even at the expense of everyone else's freedom. As we have seen, this new form of tribalism within the nation is reflected by the president's rhetorical construction of enemy figures not only located within the national territory but also within the national community. Trump's constant division between friends and foes evokes a conception of politics where groups face off as mutual enemies. Some scholars have pointed to the work of political philosopher Carl Schmitt, once infamous for having been a member of the Nazi Party and now mostly known for his political theory on dictatorship (Fuchs 2017: 58; Mohamed 2018). Schmitt saw the distinction between friends and enemies as the essence of politics, but, contrary to Schmitt's model which differentiates between private and public, Donald Trump observes no such difference. His motivation for making enemies is not primarily political, but rather personal: whoever contradicts or criticizes him is turned into a foe.

It remains that Donald Trump's presidential rhetoric shows unique authoritarian tendencies, including in the way he has turned the news media and his political rivals into enemies. It has also laid out in the open his nativism and racism, illustrated by how he has turned immigrants into racialized enemies. This seems like a disastrous combination for democracy. At the same time, his success relies on his ability to be the Entertainer-in-Chief. Referring to Mikhael Bakhtin's work on carnivalesque figures, scholars have described Trump's power as "the power of carnivalesque entertainment," noticing that entertainers, like clowns, have license to disobey rules (Hall 2017: 73; Ott and Dickenson 2017: 43-4). Trump's words and gestures can be undeniably associated with those of a clown. His own body, from the color of his skin to the look of his hair, has been the subject of mockery and entertainment as if he had been the king of carnival. It remains to be seen whether his presidency, including the way he has increased polarization by treating the government as his own enemy, will have a longterm effect on U.S. politics, institutions and government. In the meantime, more work could focus on the people that have made Trump's presidency possible, notably advisors Steve Bannon and Stephen Miller, or Senate Majority Leader Mitchell McConnell .

\section{BIBLIOGRAPHY}

Adams, John Quincy. "Speech to the U.S. House of Representatives on Foreign Policy." July 4, 1821. Transcript available at the Miller Center of Public Affairs, University of Virginia. https:// millercenter.org/the-presidency/presidential-speeches/july-4-1821-speech-us-houserepresentatives-foreign-policy 
Anderson, Benedict. Imagined Communities: Reflections on the Origin and Spread of Nationalism. London: Verso, 1983.

Ben-Porath, Eran N. "Rhetoric of Atrocities: The Place of Horrific Human Rights Abuses in Presidential Persuasion.” Presidential Studies Quarterly 47(2) 2007: 181-202. DOI: 10.1111/j. 1741-5705.2007.02593.x

Bercovitch, Sacvan. The American Jeremiad. Madison: U of Wisconsin P. UW Madison 1978. 2012.

Burke, Kenneth. Language As Symbolic Action. Berkeley: U of California P. Second Printing edition. 1968.

Butler, John R. "Somalia and the imperial savage: Continuities in the rhetoric of war." Western Journal of Communication 66(1) 2002: 1-24. DOI: 10.1080/10570310209374723

Caldwell, Wilbur. American narcissism: The Myth of National Superiority. New York: Algora Publishing, 2006.

Campbell, David. Writing Security: United States Foreign Policy and the Politics of Identity. Minneapolis: U of Minnesota P, 1992.

Carney, Zoë Hess, Mary Stuckey. "The World as the American Frontier: Racialized Presidential War Rhetoric." Georgia State University: Communication Faculty Publications, 2015: 163-188. DOI: 10.1080/1041794X.2015.1043139

Coakley, John. “'Primordialism' in nationalism studies: theory or ideology?" Nations and Nationalism 24 (2) 2018: 327-347. DOI: 10.1111/nana.12349

Coe, Kevin, Rico Neuman. "International Identity in Theory and Practice: The Case of the Modern American Presidency.” Communication Monographs 78(2) 2011: 139-161. DOI:

10.1080/03637751.2011.564641

Coles, Roberta. "War and the Contest Over National Identity." The Sociological Review 50(4) 2002. DOI: 10.1111/j.1467-954X.2002.tb02583.X

De Durand Etienne. « Des différents usages du terme « guerre » et de leur signification dans les représentations politiques américaines. » Transatlantica 12001 https://transatlantica.revues.org/ 466

Edwards, Jason, A. “Defining the Enemy for the Post-Cold War World: Bill Clinton's Foreign Policy Discourse in Somalia and Haiti." International Journal of Communication 2 2008: 830-847. https:// ijoc.org/index.php/ijoc/article/view/264

Engels, Jeremy. The Politics of Resentment: A genealogy. University Park: Penn State UP, 2015.

Finnemore, Martha. National Interests in International Society. New York: Cornell UP, 1996.

Foner, Eric. “American Freedom in a Global Age.” American Historical Review 106(1) 2001. DOI: $10.2307 / 2652222$

Frum, David. The Right Man: The Surprising Presidency of George W. Bush, an inside account. New York: Random House, 2003.

Fuchs, Christian. "Donald Trump: A Critical Theory-Perspective on Authoritarian Capitalism." TripleC: Communication, Capitalism \& Critique 15(1) 2017: 1-72. DOI: 10.31269/triplec.v15i1.835

Goodnight, Thomas. "Reagan's Reformulation of the Rhetoric of War : Analysis of the 'zero option,' 'evil empire,' and 'star wars' addresses." Quarterly Journal of Speech 72(4) 1986: 390-414. DOI: $10.1080 / 00335638609383784$ 
Grandin, Greg. The End of the Myth: From the Frontier to the Border Wall in the Mind of America. New York: Metropolitan, 2019.

Gregg, R.B. "Embodied Meaning in American Public Discourse during the Cold War", in F.A. Beer and C. De Landtsheer (eds). Metaphorical World Politics. East Lansing: Michigan State UP, 2004. 59-73.

Hall, Kira, Donna Meryl Goldstein, and Matthew Bruce Ingram. "The hands of Donald Trump: Entertainment, gesture, spectacle." HAU: Journal of Ethnographic Theory 6(2) 2016: 71-100. DOI: 10.14318/hau6.2.009

Inbar, Yoel, David Pizarro, Ravi Iyer, and Jonathan Haidt. "Disgust Sensitivity, Political Conservatism, and Voting." Social Psychological and Personality Science 3(5) 2012: 537-544. DOI: $10.1177 / 1948550611429024$

Ivie, Robert L., "Images of Savagery in American Justifications for War." Communication Monographs 47(4) 1980: 279-294. DOI: 10.1080/03637758009376037

Ivie, Robert L. "Savagery in democracy's empire." Third World Quarterly 26(1) 2005: 55-65. DOI: $10.1080 / 0143659042000322900$

Kalb Marvin, Enemy of the People: Trump's War on the Press, the New McCarthyism, and the Threat to American Democracy, Washington D.C.: Brookings Institution Press, 2018.

Miller, Susan B. "Disgust and contempt in the White House." Psychoanalysis, Culture \& Society 22 2017: 6-14. DOI: 10.1057/s41282-017-0038-z

Mohamed, Feisal. "'I Alone Can Solve': Carl Schmitt on Sovereignty and Nationhood Under Trump." In Angel Jaramillo Torres and Marc Benjamin Sable (eds.). Trump and Political Philosophy Leadership, Statesmanship, and Tyranny. Cham: Palgrave Macmillan, 2018: 293-309.

Murphy, John. “'Our Mission and Our Moment': George W. Bush and September 11th.” Rhetoric \& Public Affairs 6(4) 2003: 607-632. DOI: 10.1353/rap.2004.0013

Musolff, Andreas. Metaphor, Nation and Holocaust: The Concept of the Body Politic. London, New York: Routledge, 2010.

Noon, David H. "Operation Enduring Analogy: World War II, the War on Terror, and the Uses of Historical Memory." Rhetoric and Public Affairs 7(3) 2004: 339-366. DOI: 10.1353/rap.2005.0015

Ott, Brian L., Greg Dickinson. The Twitter Presidency: Donald J. Trump and the Politics of White Rage. New York: Routledge, 2019.

Richardson, Michael. "The disgust of Donald Trump," Continuum: Journal of media \& Cultural Studies 31(6) 2017: 747-756. DOI: 10.1080/10304312.2017.1370077

Schlesinger, Robert. White House Ghosts: Presidents and their Speechwriters from FDR to George W. Bush. New York: Simon \& Schlesinger, 2008.

Schmitt, Carl. The Concept of the Political. Chicago: U of Chicago P, 1932/1996.

Slotkin, Richard. Gunfighter Nation: The Myth of the Frontier in Twentieth-century America. New York: Harper Collins, 1993.

Stuckey, Mary. Defining Americans: The Presidency and National Identity. Lawrence: UP of Kansas, 2004.

Wander, Phillip. "The Rhetoric of American Foreign Policy." Quarterly Journal of Speech 70(4) 1984: 339-6. DOI: 10.1080/00335638409383703 
Wendt, Alexander. "Collective Identity Formation and the International State." American Political Science Review 88(2) 1994: 384-396. DOI: 10.2307/2944711

West, Mark, Chris Carey. “(Re)Enacting Frontier Justice: The Bush Administration's Tactical Narration of the Old West Fantasy after September 11." Quarterly Journal of Speech 92(4) 2006: 379-412. DOI: 10.1080/00335630601076326

\section{Press articles}

Chinoy, Sahil, Jessia Ma, and Stuart A. Thompson. "MS-13 Is Far From the 'Infestation' Trump Describes." The New York Times. July 3, 2018. https://www.nytimes.com/interactive/2018/06/27/ opinion/trump-ms13-immigration.html

Cohn, Gary D. and H.R. McMaster. “America First Doesn't Mean America Alone.” Wall Street Journal, May 30, 2017. https://www.wsj.com/articles/america-first-doesnt-mean-americaalone-1496187426

Cruz Jose Miguel. "Central American gangs like MS-13 were born out of failed anti-crime policies.” The Conversation, May 9, 2017. https://theconversation.com/central-american-gangslike-ms-13-were-born-out-of-failed-anti-crime-policies-76554

Devroy Ann, R. Jeffrey Smith. “Clinton Reexamines a Foreign Policy Under Siege.” The Washington Post, Oct. 17, 1993. https://www.washingtonpost.com/archive/politics/1993/10/17/clintonreexamines-a-foreign-policy-under-siege/794fbbd6-349c-44d4-94b2-65868bd53587/? noredirect $=$ on\&utm_term $=.2495 \mathrm{f} 91 \mathrm{~d} 5 \mathrm{aab}$

Huntington, Samuel P. “The Clash of Civilizations?” Foreign Affairs 72(3) 1993: 22-49. https:// www.foreignaffairs.com/articles/united-states/1993-06-01/clash-civilizations

Nunberg, Geoffrey. “The -Ism Schism; How Much Wallop Can a Simple Word Pack?” The New York Times, July 11, 2004. https://www.nytimes.com/2004/07/11/weekinreview/the-ism-schism-howmuch-wallop-can-a-simple-word-pack.html

Scully Matthew. "Present at the Creation.” The Atlantic, Sept. 2007. https://www.theatlantic.com/ magazine/archive/2007/09/present-at-the-creation/306134/

Viala-Gaudefroy, Jerome. "How to manufacture a crisis: Deconstructing Donald Trump's Immigration Rhetoric.” The Conversation, Feb. 11, 2019, https://theconversation.com/how-tomanufacture-a-crisis-deconstructing-donald-trumps-immigration-rhetoric-111049

\section{Corpus}

\section{George H. W. Bush}

1989-09-01, Statement on Panama-United States Relations

1989-09-05, Address to the Nation on the National Drug Control Strategy

1989-10-30, Remarks at the Groundbreaking Ceremony for the National Law Enforcement Officers' Memorial

1989-12-20, Address to the Nation Announcing United States Military Action in Panama 1990-08-08, Address to the Nation Announcing the Deployment of United States Armed Forces to Saudi Arabia 
1990-08-20, Remarks at the Annual Conference of the Veterans of Foreign Wars in Baltimore, Maryland

1990-09-11, Address Before a Joint Session of the Congress on the Persian Gulf Crisis and the Federal Budget Deficit

1990-09-16, Address to the People of Iraq on the Persian Gulf Crisis

1990-10-01, Address Before the 45th Session of the United Nations General Assembly in New York, New York

1990-10-22, Message to the Senate Returning Without Approval the Civil Rights Act of 1990

1990-10-28, Remarks to Officers and Troops at Hickam Air Force Base in Pearl Harbor, Hawaii

1990-11-04, Remarks to a Joint Session of the Congress in Montevideo, Uruguay

1990-11-22, Remarks to United States Army Troops Near Dhahran, Saudi Arabia

1990-12-24, Christmas Message to American Troops

1991-01-16, Address to the Nation Announcing Allied Military Action in the Persian Gulf 1991-01-29, Address Before a Joint Session of the Congress on the State of the Union 1991-01-30, Remarks at the 50th Anniversary Observance of Franklin D. Roosevelt's Four Freedoms Speech

1991-03-01, Remarks to the American Legislative Exchange Council

1991-03-02, Radio Address to United States Armed Forces Stationed in the Persian Gulf Region 1991-06-06, Remarks at the Simon Wiesenthal Center Dinner in Los Angeles, California 1991-06-18, Remarks at a White House Briefing for Law Enforcement Officials on Crime Legislation

1992-08-25, Remarks to the American Legion National Convention in Chicago, Illinois 1992-12-04, Address to the Nation on the Situation in Somalia 1993-01-05, Remarks at the United States Military Academy in West Point, New York,

\section{Bill Clinton}

1993-05-05, Remarks on Welcoming Military Personnel Returning From Somalia

1993-10-07, Address to the Nation on Somalia

1993-06-26, Address to the Nation on the Strike on Iraqi Intelligence Headquarters

1994-06-06, Remarks on the 50th Anniversary of D-Day at the United States Cemetery in Colleville-sur-Mer, France

1994-09-14, Interview With Wire Service Reporters on Haiti

1994-09-15, Address to the Nation on Haiti

1994-12-24, The President's Radio Address

1995-11-03, Remarks at the Dedication of the Pan American Flight 103 Memorial Cairn in Arlington, Virginia

1995-04-19, Remarks on the Bombing of the Alfred P. Murrah Federal Building in Oklahoma City, oklahoma 
1995-04-23, Remarks at a Memorial Service for the Bombing Victims in Oklahoma City, Oklahoma 1995-08-01, Teleconference Remarks to the Fraternal Order of Police 1995-10-06, Remarks at a Freedom House Breakfast 1995-11-27, Address to the Nation on Implementation of the Peace Agreement in BosniaHerzegovina 1995-11-29, Remarks to the Parliament of the United Kingdom in London).

1996-03-13, Remarks at the Opening of the Summit of the Peacemakers in Sharm al-Sheikh, Egypt 1996-03-14, Remarks and a Question-and-Answer Session With Students in Tel Aviv 1996-06-30, Remarks at the Memorial Service at Eglin Air Force Base, Florida, for American Servicemen Killed in Saudi Arabia 1996-08-08 Remarks in Long Beach, California 1997-09-22, Remarks to the 52d Session of the United Nations General Assembly in New York City 1997-09-25, Remarks on the 40th Anniversary of the Desegregation of Central High School in Little Rock, Arkansas 1998-01-27, Address Before a Joint Session of the Congress on the State of the Union 1998-06-08, Remarks to the United Nations General Assembly Special Session on the World Drug Problem in New York City 1998-09-21, Remarks to the 53d Session of the United Nations General Assembly in New York City 1999-03-24, Address to the Nation on Airstrikes Against Serbian Targets in the Federal Republic of Yugoslavia (Serbia and Montenegro)

1999-04-05, Remarks on the Situation in the Balkans and an Exchange With Reporters 1999-04-12a, Remarks at the Seventh Millennium Evening at the White House 1999-04-12b, Remarks to the Community at Barksdale Air Force Base in Bossier City, Louisiana 1999-04-24, The President's News Conference 1999-05-10, Peace Officers Memorial Day and Police Week 1999-06-02, Commencement Address at the United States Air Force Academy in Colorado Springs 1999-11-08, Remarks at Georgetown University 2000-10-12, Statement on Action To Lift Sanctions Against Serbia Union

\section{George W. Bush}

20012001-04-09, National Crime Victims' Rights Week

2001-06-06, Remarks at the Dedication of the National D-Day Memorial in Bedford, Virginia 2001-09-11, Address to the Nation on the Terrorist Attacks 2001-09-14, Remarks at the National Day of Prayer and Remembrance Service 2001-09-16, Remarks on Arrival at the White House and an Exchange With Reporters 2001-09-17, Remarks to Employees in the Pentagon and an Exchange With Reporters in Arlington, Virginia 
2001-09-20, Address Before a Joint Session of the Congress on the United States Response to the Terrorist Attacks of September 11

2001-09-25, Remarks Following Discussions With Prime Minister Junichiro Koizumi of Japan and an Exchange With Reporters

2001-10-06, The President's Radio Address

2001-10-07, Address to the Nation Announcing Strikes Against Al Qaida Training Camps and Taliban Military Installations in Afghanistan

2001-10-10, Remarks Announcing the Most Wanted Terrorists List

2001-10-21, The President's News Conference With President Vladimir Putin of Russia in Shanghai

2001-11-07, Remarks at the Financial Crimes Enforcement Network in Vienna, Virginia

2001-11-08, Address to the Nation From Atlanta on Homeland Security

2001-11-28, Remarks to the Farm Journal Forum

2001-12-20, Remarks Announcing Action Against Terrorist Financial Support Networks 2002-01-29, Address Before a Joint Session of the Congress on the State of the Union 2002-01-22, Remarks to Employees of the Cecil I. Walker Machinery Company in Belle 2002-02-16, Remarks to the Troops at Elmendorf Air Force Base in Anchorage, Alaska 2002-03-01, Remarks at a Fundraiser for Representative Tom Latham in Des Moines 2002-03-08, Remarks at a Republican Party of Florida Reception in St. Petersburg 2002-05-24, The President's News Conference With President Vladimir V. Putin of Russia in Moscow

2002-06-01, Commencement Address at the United States Military Academy in West Point, New York

2002-09-16, Remarks to the Community in Little Rock, Arkansas

2002-09-20, Proclamation 7597-Family Day

2002-10-07, Address to the Nation on Iraq From Cincinnati, Ohio

2003-03-15, The President's Radio Address 2003-01-28, Address Before a Joint Session of the Congress on the State of the Union

2003-03-17, Address to the Nation on Iraq

2003-03-19, Address to the Nation on Iraq

2003-05-23, The President's News Conference With Prime Minister Junichiro Koizumi of Japan in Crawford, Texas

2003-09-23, Address to the United Nations General Assembly in New York City

2004-03-19, Remarks on the Anniversary of Operation Iraqi Freedom

2004-09-20, Remarks and a Question-and-Answer Session in Derry, New Hampshire

2004-10-07, Statement of Administration Policy: H.R. 10 - 9/11 Recommendations

Implementation Act

2005-08-30, Remarks on the 60th Anniversary of V-J Day in San Diego, California 
2005-10-06, Remarks to the National Endowment for Democracy

2006-03-26, Remarks to Freedom House and a Question-and-Answer Session

2007-08-28, The President's Radio Address

2008-04-01, Interview With Foreign Print Media

2008-05-15, Remarks to Members of the Knesset in Jerusalem

Barack Obama:

2008-08-16, Remarks at the Saddleback Civil Forum on the Presidency in Lake Forest, California 2009-06-01, Interview With Justin Webb of BBC World News

2009-06-06, Remarks on the 65th Anniversary of D-Day in Normandy, France

2009-12-10, Remarks on Accepting the Nobel Peace Prize in Oslo

2010-05-22, Commencement Address at the United States Military Academy in West Point, New York

2010-09-11, Remarks at a Wreath-Laying Ceremony at the Pentagon Memorial in Arlington, Virginia

2010-11-06, Remarks on the Second Anniversary of the Terrorist Attacks in Mumbai, India

2011-03-11, The President's News Conference

2011-06-29, The President's News Conference

2012-03-13, Joint Op-Ed by President Obama and Prime Minister Cameron: An Alliance the World Can Count On), or about Qadhafi,

2012-05-02, Military Operations in Afghanistan From Bagram Air Base

2012-07-04, Remarks at a Naturalization Ceremony for Active Duty Servicemembers

2012-07-12, Remarks on the Shootings in Aurora, Colorado, From Fort Meyers, Florida

2013-04-16, Remarks on the Terrorist Attack in Boston, Massachusetts

2013-09-09, Interview with Wolf Blitzer of CNN's "The Situation Room",

2013-09-10, Address to the Nation on the Situation in Syria

2013-09-24, Remarks to the United Nations General Assembly in New York City

2014-09-10, Address to the Nation on United States Strategy To Combat the Islamic State of Iraq and the Levant Terrorist Organization (ISIL)

2014-09-24, Remarks to the United Nations General Assembly in New York City

2015-01-20, Address Before a Joint Session of the Congress on the State of the Union

2015-02-19, Remarks at the White House Summit on Countering Violent Extremism

2015-07-06, Remarks on United States Efforts To Combat the Islamic State of Iraq and the Levant (ISIL) Terrorist Organization and an Exchange With Reporters

2015-07-10, Statement on the 20th Anniversary of the Srebrenica Genocide

2015-09-29, Remarks at the United Nations Leaders' Summit on Countering ISIL and Violent Extremism in New York City

2016-02-03, Remarks at the Islamic Society of Baltimore in Catonsville 


\section{Donald Trump}

2015-06-16, Remarks Announcing Candidacy for President in New York City

2015-12-7, Donald Trump in Mt. Pleasant, SC

2016-03-09, Interview with CNN's Anderson Cooper

2017-01-20, Inaugural Address

2017-01-25, Executive Order: Border Security and Immigration Enforcement Improvements

2017-01-21, Remarks at the Central Intelligence Agency in Langley, Virginia

2017-02-24, Remarks at the Conservative Political Action Conference (CPAC) in National Harbor, Maryland

2017-02-28, Address Before a Joint Session of the Congress

2017-04-05, Press Conference: Donald Trump and King Abdullah II Hold a Joint Press Conference

2017-04-18, Donald Trump With Ainsley Earhardt on Fox and Friends

2017-04-28, Remarks at the National Rifle Association Leadership Forum in Atlanta, Georgia

2017-04-29, Donald Trump Holds a Political Rally in Harrisburg, Pennsylvania

2017-05-21, Remarks at the Arab Islamic American Summit in Riyadh, Saudi Arabia

2017-05-25, Remarks at the Dedication Ceremony for the Berlin Wall Memorial and the $9 / 11$ and Article 5 Memorial in Brussels, Belgium

2017-05-26, Statement on the Terrorist Attack in Minya Province, Egypt

2017-07-06, Remarks in Warsaw, Poland

2017-07-12, CBN: Pat Robertson Interviews Donald Trump

2017-07-25, Rally of Supporters in Youngstown, Ohio

2017-09-17, Remarks at a Wreath-Laying Ceremony at the Pentagon Memorial in Arlington, Virginia

2017-09-26, Press Conference: Donald Trump and Mariano Rajoy of Spain

2017-10-02, Remarks on the Shootings in Las Vegas, Nevada

2017-10-06, Remarks at a Hispanic Heritage Month Reception

2017-10-26, Remarks on Signing a Memorandum on Combatting the National Drug Demand and Opioid Crisis

2017-11-01, Remarks: Donald Trump Attends a Cabinet Meeting

2017-12-08, Remarks at a "Make America Great Again" Rally in Pensacola, Florida

2017-12-16, The President's Weekly Address

2017-12-18, Remarks on the 2017 National Security Strategy

2018-01-30, Address Before a Joint Session of the Congress on the State of the Union

2018-02-23, Remarks at the Conservative Political Action Conference (CPAC)

2018-03-10, Remarks at a "Make America Great Again Rally” Moon Township, Pennsylvania 
2018-04-13, Remarks: Donald Trump Announces Missile Strikes Against Syria

2018-04-18, The President's Weekly Address

2018-05-08, Donald Trump Holds a Political Rally in Panama City Beach, Florida

2018-05-29, Donald Trump Holds a Political Rally in Nashville, Tennessee

2018-05-23, Remarks During a Roundtable Discussion on Immigration in Bethpage, New York

2018-06-22, Remarks: Donald Trump Delivers Remarks on Immigration to Families of Crime Victims

2018-08-02, Donald Trump Holds a Political Rally in Wilkes-Barre, Pennsylvania

2018-10-09, Remarks in an Exchange With Reporters Prior to Departure for Council Bluffs, Iowa

2018-10-30, Remarks at a "Make America Great Again" Rally in Estero, Florida

2018-10-31a, Political Rally in Fort Myers, Florida

2018-10-31b, David Brody and Jenna Browder from CBN Interview Donald Trump

2018-12-26, Donald Trump Speaks to Troops at Al Asad Air Base in Iraq

2019-01-10, A Roundtable on Border Security in McAllen, Texas

2019-01-25, Donald Trump Announces Deal to End Government Shutdown From Rose Garden

2019-02-05, Donald Trump Delivers the State of the Union

2019-02-15, Remarks on Declaring a National Emergency Concerning the Southern Border of the United States and an Exchange With Reporters

2019-02-21, Remarks: Donald Trump Attends a Reception for African American History Month 2019-03-13, Donald Trump Receives a Briefing on on Drug Trafficking

2019-03-25, Remarks Following a Meeting With Prime Minister Benjamin Netanyahu of Israel and an Exchange With Reporters

2019-05-20, Donald Trump, Political Rally in Montoursville, Pennsylvania

2019-06-04, Donald Trump and Theresa May Hold a Joint Conference in London

2019-06-06, Speech: Donald Trump Attends a 75th Anniversary D-Day Commemoration Event in France.

2019-10-17, Donald Trump Holds a Political Rally in Dallas, Texas

\section{NOTES}

1. As political scholar John Coakley explains, nationalists hold what is sometimes called a "primordialist" view, which "stresses the deep historical and cultural roots of nations" and is hard to find in academic literature where there tends to be a "constructivist consensus" (Coakley 2018: 327).

2. No other nation has invented an adjective like "Un-American" to qualify Other, either foreign or domestic (Michael Kammen qtd. in Campbell 1992: 105).

3. As Eran Ben-Porath notes, "that the tale was concocted by a lobbying firm hired by the Kuwaiti government and the young girl giving testimony was the daughter of a Kuwaiti diplomat would be revealed only after the war." (Ben-Porath 2007: 189). 
4. American Heritage dictionary online $:$ https://ahdictionary.com/word/search.html?q=outlaw

5. According to an article in the New York Times, if the viciousness of MS-13 is a reality, they actually "make up less than $1 \%$ of the gang members in the United States," and "their numbers are stagnant" and more generally "few immigrants commit violent crimes." (Chinoy et al. 2018)

\section{ABSTRACTS}

If identity is developed in relation to the Other, as researchers in the social sciences claim, then a nation's sense of self must also be, to some degree, contingent on its understanding of what constitutes the Other. This constructive perspective is all the more useful if we consider nations to be "imagined communities" (Anderson). In this respect, the American identity is probably the best example of a "self" understood through "otherness." Research in various disciplines has shown that Americans have long defined themselves through a binary narrative of "us" versus "them" (Butler; Coe-Neuman; Campbell; Edwards; Schlesinger). Whether it takes the form of the American Indians of the Frontier, the British during the American Revolution, the immigrants in the early $20^{\text {th }}$ century, the Nazis, the Communists, and more recently the terrorists, this Other has three constant characteristics: it is always deemed a threat, somewhat uncivilized and evil, and serves to define national identity by demarcating an "inside" from an "outside," a "self" from an "other," a "domestic" from a "foreign", "civilization" from "savagery" and "good" from "evil" (Butler; Campbell; Ivie; Slotkin). As the embodiment of the nation, the president is central to this construction of the U.S. national identity and he takes on the role of storyteller-in-chief. As Chief Executive and Commander-in-Chief of the armed forces, he also has the responsibility to protect the nation and define which threats may attack it. Scholars in communication have shown that the principal image of the enemy in presidential discourse is the "Savage Other" (Ivie; Coe; Neuman). This enemy can be categorized as either "primitive" or "modern." The former is portrayed as a decentralized enemy living in a primitive society of instability and chaos, devoid of civilization, whereas the latter is considered a centralized evil agent that has "some semblance of civilization" but is nonetheless savage because their aim is to destroy America's civilized order (Butler). We will begin by showing how one of the distinctive features of America's enemies has been their evil nature, a charge which reflects the fusion of religious and secular elements that typifies U.S. presidential rhetoric. Then, after looking over the history and definition of the "savage other", we will discuss how the period since the end of the Cold War, now lacking in "identifiable monolithic enemies" (Edwards), is characterized by a resurgence of the figure of the "primitive savage" presented through a series of animal and sexual images and scenery that turn the evil Other into a predator, not unlike the Indian of the Frontier, while making America the heroic figure of the story. Then, we will show how America's enemy is also strategically framed as a "modern savage" in the months and weeks leading up to major conflicts, such as the Iraq war. Only an enemy capable of destroying America's order can constitute a powerful enough threat justifying a full-blown war. Finally, we will try to assess Donald Trump's disruptive use of the enemy image which, contrary to all his recent predecessors, he applies to entities located both inside and outside the national space, such as immigrants or news media deemed "the enemy of the people." We will conclude by hypothesizing that President Trump's highly gendered and racialized enemy rhetoric is emblematic of a nationalist discourse of exclusion and purification of the social body motivated by a fear of fluidity of various identities in an increasingly multicultural society, hence the importance of claiming clear demarcation. 
L'identité se construit en relation à un «Autre » au niveau individuel comme national. Ce point de vue constructiviste est illustré par la définition d'une nation comme des "communautés imaginées » (Anderson). Or, l'identité américaine est sans doute le meilleur exemple d'un " Soi » compris à travers l'altérité. La recherche dans diverses disciplines démontre combien les Américains se définissent au travers d'un récit binaire qui oppose un «nous " à un "eux » (Butler ; Coe-Neuman ; Campbell ; Edwards ; Schlesinger). Qu'il prenne la forme des Indiens du Far West, des Britanniques pendant la guerre d'indépendance, des immigrés au début du $20^{\mathrm{e}}$ siècle, ou des nazis, des communistes, ou des terroristes, cet "Autre " a des caractéristiques constantes : il est toujours perçu comme une menace, il est dépeint comme sauvage et maléfique, et il sert à définir l'identité nationale en fixant une limite entre "intérieur » et " extérieur ",

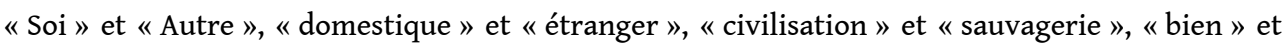
«mal» (Butler; Campbell ; Ivie ; Slotkin). Au cœur de cette construction se trouve le président qui, en tant qu'incarnation de la nation, prend le rôle de «conteur en chef ». Des chercheurs en communication ont montré que l'image principale de l'ennemi dans les discours présidentiels est celle de « l'Autre sauvage » (Ivie ; Coe ; Neuman). Cet ennemi peut être classé en deux catégories : "primitif» et «moderne ». Le premier est présenté comme un ennemi décentralisé qui vit dans une société primitive dépourvue de toute civilisation, où règne le chaos, tandis que le second, dit "moderne », a " un semblant de civilité » mais est, par son action, sorti du monde civilisé, incarné par les valeurs américaines (Butler). S’appuyant sur la recherche dans les domaines de la communication, de la linguistique cognitive, de la sociologie, des sciences politiques et de la philosophie politique, cet article se focalise sur la façon dont les présidents américains ont construit l'image des ennemis de la nation depuis la fin de la guerre froide, à travers des métaphores, analogies, et tropes spécifiques. Tout d'abord, nous verrons que l'un des traits distinctifs des ennemis de l'Amérique est leur nature maléfique, une caractéristique qui reflète la fusion du discours religieux et laïque. Puis, nous examinerons que la période post-guerre froide, qui n'offre plus un ennemi «monolithique identifiable», se caractérise par la résurgence de la figure du "sauvage primitif " présenté à travers une série de caractéristiques qui font de « l'Autre sauvage » un prédateur, ce qui n'est pas sans rappeler l'image de l'Indien du Far West, tout en donnant à l'Amérique le rôle de héros. Nous montrerons également que les tentatives de reconstruction d'un "sauvage moderne" répondent aux besoins politiques de posséder un ennemi assez puissant pour constituer une menace et justifier une guerre à part entière. Enfin, nous évaluerons l'utilisation subversive de l'image de l'ennemi par Donald Trump qui, contrairement à ses prédécesseurs, l'associe à des entités localisées tant à l'extérieur qu'à l'intérieur de l'espace national. Nous évoquerons la possibilité que la rhétorique du président Trump soit emblématique d'un discours nationaliste d'exclusion et de purification du corps social, motivé par la peur de la fluidité dans un monde de plus en plus multiculturel, qui met en exergue, des lignes de démarcation identitaire claires.

\section{INDEX}

Keywords: American presidential rhetoric, enemy, evil, foreign policy, identity, Self, Other, savage, Indians, Frontier, post-Cold War, war, Bush George H., Clinton Bill, Bush George W., Obama Barack, Trump Donald, disgust

Mots-clés: rhétorique présidentielle, ennemi, mal, politique internationale, identité, identité nationale, Soi, Autre, sauvage, Indiens, Far West, post-guerre froide, guerre, Bush George H., Clinton Bill, Bush George W., Obama Barack, Trump Donald, dégoût 


\section{AUTHOR}

\section{JÉRÔME VIALA-GAUDEFROY}

Part-time lecturer at Institut d'étude politiques in Saint-Germain-en-Laye. Jérôme Viala-

Gaudefroy holds an agrégation in English and defended his thesis in 2016. His research focuses on presidential rhetoric in the post-Cold War era. He published an article on "President Trump and the Virtue of Power" in the e-journal LISA, vol. XVI-n ${ }^{\circ} 2$ in 2018 . He is also a regular contributor to the independent, not-for-profit online publication, The Conversation. He was the webmaster of the AFEA (Association française d'études américaines) from 2013 to 2020 and remains an active member of the board. Contact information: jeromevg[at]gmail.com 